\title{
Sex steroids differentially regulate fshb, Ihb and gnrhr expression in Atlantic cod (Gadus morhua) pituitary
}

\author{
Kristine von Krogh ${ }^{1}$, Gunnveig Toft Bjørndal ${ }^{2}$, Rasoul Nourizadeh-Lillabadi ${ }^{1}$, Kjetil Hodne $^{1}$, \\ Erik Ropstad $^{3}$, Trude M Haug ${ }^{2,4}$ and Finn-Arne Weltzien ${ }^{1}$ \\ ${ }^{1}$ Department of Basic Sciences and Aquatic Medicine, Norwegian University of Life Sciences, Oslo, Norway, \\ ${ }^{2}$ Department of Biosciences, University of Oslo, Oslo, Norway, ${ }^{3}$ Department of Production Animal Clinical Sciences, \\ Norwegian University of Life Science, Oslo, Norway and ${ }^{4}$ Department of Oral Biology, University of Oslo, \\ Oslo, Norway \\ Correspondence should be to F-A Weltzien; Email: finn-arne.weltzien@nmbu.no
}

\begin{abstract}
Depending on the stage of gonad maturation, as well as other factors, gonadal steroids can exert either a positive or negative feedback at the brain and pituitary level. While this has been demonstrated in many teleost species, little is known about the nature of steroid feedback in Gadiform fish. Using an optimized in vitro model system of the Atlantic cod pituitary, the present study investigated the potential effects of two physiologically relevant doses of estradiol, testosterone (TS) or dihydrotestosterone (DHTS) on cell viability and gene expression of gonadotropin subunits $(f s h b / / h b)$ and two suggested reproduction-relevant gonadotropinreleasing hormone receptors (gnrhr1b/gnrhr2a) during three stages of sexual maturity. In general, all steroids stimulated cell viability in terms of metabolic activity and membrane integrity. Furthermore, all steroids affected fshb expression, with the effect depending on both the specific steroid, dose and maturity status. Conversely, only DHTS exposure affected Ihb levels, and this occurred only during the spawning season. Using single-cell qPCR, co-transcription of gnrhr1b and gnrhr2a was confirmed to both fshb-and Ihb- expressing gonadotropes, with gnrhr2a being the most prominently expressed isoform. While steroid exposure had no effect on gnrhr1b expression, all steroids affected gnrhr2a transcript levels in at least one maturity stage. These and previous results from our group point to Gnrhr2a as the main modulator of gonadotropin regulation in cod and that regulation of its gene expression level might function as a direct mechanism for steroid feedback at the pituitary level.

Reproduction (2017) 154 581-594
\end{abstract}

\section{Introduction}

Sexual maturation in fish, as in other vertebrates, is controlled by the physiological connection between the brain-pituitary-gonad (BPG) axis compartments; gonadotropin-releasing hormone (Gnrh) secreted from hypothalamic neurons onto the pituitary stimulates the synthesis and release of follicle-stimulating hormone (Fsh) and luteinizing hormone (Lh), which in turn stimulate gonadal steroidogenesis and gametogenesis. Although the exact mechanisms are not known, activation of the Gnrh system seems to be the key event in the onset of teleost puberty (Weltzien et al. 2004). Gnrh exerts its action via specific Gnrh receptors (Gnrhr) located in target cell membranes. Several isoforms of Gnrhr exist in teleosts, and these may be differentially expressed during maturation and spawning. In Atlantic cod (Gadus morhua), four Gnrhr gene orthologues (gnrhr1b, gnrhr2a, gnrhr2b and gnrhr2c) have been identified (Hildahl et al. 2011), all of which were expressed in the brain, and three of which (gnrhr1b, gnrhr2a and gnrhr2c) were expressed in the pituitary. The expression of gnrhr2c was low and not seasonally regulated, while gnrhr1b expression showed increasing trends in expression during the mature and spent stages. gnrhr2a expression appeared to be closely correlated to gonadal maturation, indicating this forms the most likely mediator of the gonadotrope Gnrh response. Unlike mammals, teleost fish have two types of gonadotropes, individually producing either Fsh or Lh. Gnrh has been shown to stimulate both $f_{s} h b$ - and $/ h b$-expressing cells in cod (Hodne et al. 2013), but the Gnrh receptor type expressed in individual gonadotropes is yet to be determined.

The activation of the BPG axis and pubertal development is under the control of both external and internal factors, as well as feedback mechanisms within the axis itself (Dufour et al. 2010, Levavi-Sivan et al. 2010, Taranger et al. 2010, Zohar et al. 2010) and ensures that reproduction occurs at a time of optimal survival of the offspring. The synthesis and/or release of gonadotropins 
due to sex steroid feedback has been confirmed in several teleost species by measuring protein or transcript levels after steroid supplementation/replacement in vivo or after steroid exposure in vitro (Billard 1978, Kobayashi et al. 1989, Larsen \& Swanson 1997, Borg et al. 1998, Holland et al. 1998, Khan et al. 1999, Cavaco et al. 2001, Huggard-Nelson et al. 2002, Aroua et al. 2007). The nature of the feedback can differ depending on maturational stage, hormone concentration, species, sex and other factors (Saligaut et al. 1999, Okuzawa 2002, Yamaguchi et al. 2006, and see Levavi-Sivan et al. 2010 and references therein).

Atlantic cod is a marine multibatch spawner with group-synchronous gonadal development, and spawns multiple times from February until May (Brander 1994). Reports describing the gonadotropic interplay in multibatch spawners are scarce compared to single batch spawners such as salmonids and eel, and little is known on the role of steroid feedback at this level in Atlantic cod or in Gadiformes in general. In contrast to single or total spawners, in which gametes develop synchronously, both multibatch and daily spawners display gametes at different stages of development at any one time. These two contrasting spawning strategies probably display differences in the gonadotropin regulation of gametogenesis, including different responses to circulating steroids at the higher levels of the BPG axis.

The objective of the present study was to investigate direct effects of sex steroid exposure on pituitary gonadotropin and Gnrhr gene expression during different stages of sexual maturity in Atlantic cod, using dispersed pituitary primary cultures as the model system. To acquire a greater understanding of the regulatory elements in gonadotropes, a secondary objective was to identify the expression profiles of gnrhr isoforms in individual $f_{s} h b$ - and $/ h b$-producing pituitary cells.

\section{Materials and methods}

\section{Animals}

Wild Atlantic cod $(0.51-4.10 \mathrm{~kg}$ body weight) of both sexes were caught by trawling on the south coast of Norway. Following capture, fish were immediately transported to the University of Oslo and kept in recirculating aquaria supplied with $28 \%$ seawater. Fish were kept under ambient conditions of temperature $\left(8-12^{\circ} \mathrm{C}\right)$ and photoperiod $\left(60^{\circ} \mathrm{N}\right)$, and fed daily with frozen shrimp. All animals were kept and handled in agreement with the provisions enforced by the Norwegian Animal Research Authority. A specific approval for this study was not needed, as the animals themselves were not experimentally treated (Norwegian legislation for use of animals in research, Chapter II, §6). All procedures were approved by the Ethical Committee for Animal Experiments at the University of Oslo.

\section{Dispersed pituitary cell cultures}

Dispersed primary cultures of mixed sexes were prepared from pituitaries according to Hodne and coworkers (2012), with culture conditions optimized for Atlantic cod parameters in respect to osmolality, temperature, $\mathrm{pCO}_{2}$ and $\mathrm{pH}$. The optimized conditions allowed the pituitary cultures to be physiologically stable and viable for at least two weeks (see Supplementary data and Hodne et al. 2012, see section on Supplementary Data given at the end of this article). The pituitaries were sampled throughout the year to reflect different reproductive stages of cod, from maturation to the spent stage. Maturational status was determined based on macroscopic inspection of the gonads (see Supplementary data) and gonadosomatic index (GSI; (gonad weight/total body weight $\times 100$ ). Six cultures were included in the experiment, two from each of the following maturity stages; maturing, mature and spent.

In short, dissected pituitaries were pooled $(n=5-15)$, washed with modified phosphate-buffered saline (PBS; Life Technologies) and chopped into approximately $1 \mathrm{~mm}^{3}$ pieces, before being treated with trypsin (type II-S, Sigma; $1 \mathrm{mg} / \mathrm{mL}$ PBS). The trypsin digestion was ended by replacing the solution with PBS containing trypsin inhibitor (type I-S, Sigma; $1 \mathrm{mg} / \mathrm{mL}$ ) supplemented with approximately $1 \mu \mathrm{g} / \mathrm{mL}$ DNasel (Sigma). Next, the tissue fragments were mechanically dissociated in ice-cold PBS, before the solution was filtered and centrifuged. Subsequently, the pellet was resuspended in modified L-15 and the dispersed cells seeded at a density of $1.5 \times 10^{5} \mathrm{cells} / \mathrm{cm}^{2}$ in 24/96-well plates (Corning) precoated with poly-L-lysine $(0.1 \mathrm{mg} / \mathrm{mL}$, Sigma $)$. The cells were incubated at $12^{\circ} \mathrm{C}$ in a humidified atmosphere of $0.5 \% \mathrm{CO}_{2}$ in air $\left(\mathrm{pCO}_{2} ; 3.8 \mathrm{mmHg}\right.$, which resulted in a medium $\mathrm{pH}$ of 7.85). After $24 \mathrm{~h}$, medium was replaced to remove damaged and detached cells.

\section{Steroid exposure}

Stock solutions of $17 \beta$-estradiol (E2), testosterone (TS) and the non-aromatizable androgen dihydrotestosterone (DHTS) (all from Sigma) were prepared by dissolving the steroids in $100 \%$ ethanol (EtOH; Kemetyl, Kolbotn, Norway). Stock solutions were stored at $-20^{\circ} \mathrm{C}$ for no longer than 3 months and diluted in modified L-15 medium before cell exposure. To prevent possible reactions between steroids and plastic, all solutions were prepared in sterile glass tubes. The working solutions for exposure had an $\mathrm{EtOH}$ concentration of $0.2 \%$. For each experiment, two controls, either with or without EtOH were included. At day 4 of culture, the cells were exposed to either a low or high physiologically relevant dose of steroid (E2; 2.5 and $25 \mathrm{ng} / \mathrm{mL}\left(\sim 9.2 \times 10^{-9}\right.$ and $\left.9.2 \times 10^{-8} \mathrm{M}\right)$, TS and DHTS; 2 and $20 \mathrm{ng} / \mathrm{mL}\left(\sim 6.9 \times 10^{-9}\right.$ and $\left.\left.6.9 \times 10^{-8} \mathrm{M}\right)\right)$ (Dahle et al. 2003, Norberg et al. 2004, Almeida et al. 2009) and incubated for an additional $72 \mathrm{~h}$. Solvent control cells were exposed to $0.2 \%$ $\mathrm{EtOH}$ in the same manner. For gene expression analysis, six replicate wells in 24-well plates per treatment were prepared, whereas for viability tests, six replicate wells in 96-well plates were used. 


\section{Viability testing}

A classical approach to measure cell viability is using the vital stain Trypan blue. However, in cod pituitary cultures, a proportion of the cells appear naturally blue under the microscope, making this approach suboptimal (see Supplementary data). So to gain information about the condition of the cells after 7 days in culture (w/wo exposure), viability tests were performed using two non-toxic fluorescent indicator dyes, AlamarBlue $(\mathrm{AB})$ and 5-carboxyfluorescein diacetateacetoxymethyl ester (CFDA-AM) (both from Life Technologies). Both assays measure the conversion of a non-fluorescent dye into a fluorescent dye by enzymes present in intact and viable cells and indicate metabolic activity and plasma membrane integrity respectively (Bopp \& Lettieri 2008). Test procedures were carried out as described in Hodne and coworkers (2012). In short, cells were seeded, incubated and exposed to steroids as described previously. As a positive control for cell toxicity, an additional set of wells were prepared and incubated in modified L-15 medium. At day 6, the medium of these cells was replaced with L-15 supplemented with 2.5, 0.625 or $0.156 \mathrm{mM} \mathrm{CuSO}_{4}(n=6)$. At the highest concentration, $\mathrm{Cu}^{2+}$ is lethal to the cells. The $\mathrm{CuSO}_{4}$ wells were included on every plate used in the viability assays and served as both intra- and inter-assay-positive controls.

At day 7 , the culture medium in all wells was replaced with $100 \mu \mathrm{L}$ Tris buffer $(50 \mathrm{mM}, \mathrm{pH}$ 7.5) containing both $5 \% \mathrm{AB}$ and $4 \mu \mathrm{M}$ CFDA-AM (from $4 \mathrm{mM}$ stock in DMSO). After $30 \mathrm{~min}$ of incubation, the concentration of the fluorescent products was measured simultaneously for both probes with a BioTek FLX 800 fluorescence plate reader (Bio-Tek Instruments Inc., Winooski, VT, USA) and the software Gen5 was used for data collection (Gen5 Data Analysis Software, Bio-Tek Instruments Inc.).

\section{Quantification of gene expression}

\section{RNA extraction and CDNA synthesis}

Cells used for gene expression analysis were harvested at day 7 of culture. A cell lysate was produced by removing the culture medium, washing with ice-cold PBS, adding $1 \mathrm{~mL}$ TRIzol (Life Technologies) and stirring the well content with a pipette. The lysate was transferred to an Eppendorf tube and instantly frozen in liquid $\mathrm{N}_{2}$ and stored at $-80^{\circ} \mathrm{C}$. Total RNA was extracted in TRIzol following standard procedures, with the exception of adding $1.5 \mu \mathrm{L}$ GlycoBlue (Ambion, Life Technologies) to the isopropanol step for visualization of the RNA pellet. The RNA was resuspended in $10 \mu \mathrm{L}$ RNase-free water (Ambion). DNasetreated RNA (TURBO DNase-free (Ambion)) was quantified spectrophotometrically (NanoDrop, Thermo Scientific, Wilmington, DE, USA), and the quality was assessed by electrophoretic validation (Bioanalyzer, Agilent Technologies) of the RNA integrity number (RIN). Only RNA samples with RIN number above 8 were analyzed further. First-strand cDNA synthesis was performed on $500 \mathrm{ng}$ total RNA using random hexamer primers and Super Script III (Life Technologies), according to standard procedures, and stored at $-20^{\circ} \mathrm{C}$ until qPCR.

\section{Primers and reference genes}

The qPCR primers were designed using Primer3 shareware (http://frodo.wi.mit.edu/primer3/input.htm). Potential primers were further analyzed using Vector NTI (Life Technologies) to test for possible hairpin loops and primer dimer formations (Table 1 for sequence details). In each pair, one primer was targeted to an exon-exon border to avoid amplification of genomic DNA. The expression of four different genes specifically related to pituitary function was investigated, i.e., fshb (GenBank ID: DQ402373), Ihb (GenBank ID: DQ402374), gnrhr1b (GenBank ID: GU332297) and gnrhr2a (GenBank ID: GU332298.1). To allow accurate normalization of the qPCR, the stability of four reference genes, arp2, bactin, ubiquitin and ef1a was tested using Bestkeeper Software (Pfaffl et al. 2004), giving Cq geometric means and standard deviations $( \pm \mathrm{Cq})$ of $27.06( \pm 0.39), 21.96$ $( \pm 0.45), 22.19( \pm 0.43)$ and $20.40( \pm 0.39)$ respectively. For subsequent experiments, ef1a was used for normalization of the qPCR data.

Table 1 qPCR primers used in the present study.

\begin{tabular}{|c|c|c|c|c|}
\hline Target & Reference & Primer sequence & Amplicon size (nt) & Efficiency \\
\hline \multirow[t]{2}{*}{ Ihb } & Hodne et al. (2010) & Forward: 5'-GTGGAGAAGAAGGGCTGTCC-3' & 81 & 1.93 \\
\hline & & Reverse: 5'-GGACGGGTCCATGGTG-3' & & \\
\hline \multirow[t]{2}{*}{$f_{s h b}$} & Hodne et al. (2010) & Forward: 5'-GAACCGAGTCCATCAACACC-3' & 63 & 1.84 \\
\hline & & Reverse: 5'-GGTCCATCGGGTCCTCCT-3' & & \\
\hline \multirow[t]{2}{*}{ gnrhr1b } & This study & Forward: 5'-GCTACTCCCGAATCCTCCTC-3' & 73 & 1.96 \\
\hline & & Reverse: 5'-CGCCTCAGGTATGACTCTCC-3' & & \\
\hline \multirow[t]{2}{*}{ gnrhr2a } & This study & Forward: 5'-TTCACCTTCTGCTGССТСТT-3' & 113 & 1.99 \\
\hline & & Reverse: 5'-TCCGTGGAGGAAAGATTGTC-3' & & \\
\hline \multirow[t]{2}{*}{ bactin } & Hodne et al. (2012) & Forward: 5'-TTCTACAACGAGCTGAGAGTGG-3 & 102 & 1.84 \\
\hline & & Reverse: 5'-CATGATCTGGGTCATCTTCTCC-3 & & \\
\hline \multirow[t]{2}{*}{ arp2 } & Hodne et al. (2012) & Forward: 5'-GGAGGTTAGAAGTAGCAAGGAGC-3' & 107 & 1.94 \\
\hline & & Reverse: 5'-TGCTGACTCTCACGGAGTTG-3' & & \\
\hline \multirow[t]{2}{*}{ ef1a } & Hodne et al. (2010) & Forward: 5'-CCTTCAACGCCCAGGTCAT-3' & 100 & 1.92 \\
\hline & & Reverse: 5'-AACTTGCAGGCGATGTGA-3' & & \\
\hline \multirow{2}{*}{ ubiquitin } & Hodne et al. (2012) & Forward: 5'-TGTCAAAGCCAAGATTCAGG-3' & 111 & 1.86 \\
\hline & & Reverse: 5'-TGGATGTTGTAATCCGAGAGG-3' & & \\
\hline
\end{tabular}




\section{$q P C R$ analysis}

qPCR analyses were carried out using the LightCycler 480 platform (Roche), as described previously (Weltzien et al. 2005, Hodne et al. 2012). All samples were run in duplicate, and in every round, three non-template negative control (NTC) reactions were conducted for each primer pair by substituting the cDNA template with nuclease-free water (Ambion). In addition, to account for plate-to-plate variation, a standard positive calibrator control in triplicate was included on every plate. Each PCR reaction $(10 \mu \mathrm{L})$ mixture contained $5 \mu \mathrm{L}$ of SYBR Green I master mix (Roche), $1 \mu \mathrm{L}(5 \mu \mathrm{M})$ of forward primer, $1 \mu \mathrm{L}(5 \mu \mathrm{M})$ of reverse primer and $3 \mu \mathrm{L}$ of diluted $(1: 10)$ cDNA. The qPCR reactions were carried out using an initial step for $10 \mathrm{~min}$ at $95^{\circ} \mathrm{C}$ to activate the $\mathrm{Taq}$ polymerase, followed by 42 cycles consisting of $10 \mathrm{~s}$ at $95^{\circ} \mathrm{C}$ (denaturation), $10 \mathrm{~s}$ at $60^{\circ} \mathrm{C}$ (annealing) and elongation at $72^{\circ} \mathrm{C}$ for $6 \mathrm{~s}$. The fluorescence was measured after each elongation and used for determining the quantification cycle values $(\mathrm{Cq})$. A melting curve analysis was performed directly following the PCR by continuously reading the fluorescence while slowly heating the reaction mixture from $65^{\circ} \mathrm{C}$ to $98^{\circ} \mathrm{C}$. qPCR efficiencies (E) were determined based on cDNA dilution curves, which, together with the $\mathrm{Cq}$ values, were used to calculate the relative expression (Pfaffl 2001, Roche 2001):

\section{Relative expression $n=$$$
\mathrm{E}_{\text {target }}^{\Delta \mathrm{Cq}(\text { calibrator-sample) }} * \mathrm{E}_{\text {reference }}^{\Delta \mathrm{Cq}(\text { sample-calibrator) }}
$$

The qPCR assay specificity was confirmed by agarose gel electrophoresis and sequencing.

\section{Single-cell $q P C R$}

In order to analyze gnrhr expression patterns in individual gonadotropes, qPCR was performed on transcripts harvested from single cells, as described by Hodne and coworkers (2010). To secure single-cell transcripts, the patch-clamp technique in whole cell configuration was used. During these experiments, cells were maintained in artificial extracellular solution (EC) comprising (mM): $150 \mathrm{NaCl}, 5 \mathrm{KCl}, 2.4 \mathrm{CaCl}_{2}, 1.3 \mathrm{MgCl}_{2}, 1.8$ glucose and $10 \mathrm{HEPES} / \mathrm{NaOH}(\mathrm{pH} 7.85)$ at $12^{\circ} \mathrm{C}, 320$ mosmol. Patch pipettes were made from borosilicate glass with filament and had a resistance between 2 and $5 \mathrm{M} \Omega$. Before fire polishing, the patch pipettes were silanized (Sigmacote, Sigma) to prevent extracellular contamination from attaching to the glass surface. The patch pipettes were filled with ribonucleasefree intracellular solution $(\mathrm{mM}): 120 \mathrm{CH}_{3} \mathrm{SO}_{3} \mathrm{~K}, 20 \mathrm{KCl}, 10$ HEPES/NaOH, 20 sucrose ( $\mathrm{pH} 7.2$ ), 290 mosmol. Following whole cell configuration, the cytosol was harvested into the pipette by applying gentle suction through tubing connected directly to the pipette holder. The cell content was transferred to $0.5 \mathrm{~mL}$ RNase-free tubes immediately after harvesting for RNA linear pre-amplification using MessageBOOSTER cDNA Synthesis Kit (Epicenter Biotechnologies, Madison, WI, USA). Transferred cytosol from individual cells was eluted into $3 \mu \mathrm{L}$ of Quick Extract solution from the MessageBOOSTER cDNA Synthesis Kit together with Oligo(dT) primer containing a T7 promoter and SuperScript III (Life Technologies). Reverse transcriptase was used to synthesize first-strand cDNA from
poly(A) RNA. After the second-strand cDNA synthesis, a highyield in vitro transcription reaction was used to amplify the poly(A) RNA (mRNA). All single-cell gPCR was performed on cells from sexually mature cod, sampled during the spawning season.

\section{Statistical analysis}

Statistical analysis was performed using the JMP Pro12 software (SAS Institute Inc, Cary, NC, USA). Fold-changes of exposed samples relative to their respective solvent control mean were calculated and used in the subsequent analysis for both gene expression and viability data. To maintain control variance in the data set, each control sample was calculated in the same manner and included in the analysis. All data were tested for normality using the Shapiro-Wilk $W$ test. In case of non-normality, log-transformed data gave a satisfactory fit to the normal distribution. Potential differences between control cells w/wo EtOH were tested by a one-way ANOVA. Differences in gene expression or viability between treatments were investigated with the Tukey-Kramer HSD test. Significance level was set to 0.05 .

\section{Results}

\section{Solvent control}

For every primary cell culture, control wells with and without $0.2 \% \mathrm{EtOH}$ (solvent) in the media were prepared. Viability assays performed on these cells revealed a significant negative effect from $\mathrm{EtOH}$ on both metabolic (mitochondrial) activity and membrane integrity (data not shown). However, gPCR analysis did not detect any influence on gene expression from the solvent (data not shown). Note that data from steroid exposed cells in the following sections are compared to effects seen in solvent control cells.

\section{Cod pituitary cell viability after 7 days of primary culture}

In general, $72 \mathrm{~h}$ of sex steroid exposure increased both metabolic activity (AB assay) and membrane integrity (CFDA-AM assay) (Figs 1, 2 and 3), with strong correlation between effects from each assay. No negative effects from the steroids were detected.

E2 exposure significantly increased viability compared to solvent control during all three reproductive stages (Fig. 1), with the exception of cells from maturing fish exposed to low $(2.5 \mathrm{ng} / \mathrm{mL})$ dose, which showed no effect from the treatment.

Androgen treatment significantly increased metabolic activity in cells from maturing and mature fish. Interestingly, in cells from mature fish the low dose $(2 \mathrm{ng} / \mathrm{mL})$ of DHTS gave a significantly stronger effect on metabolic activity than the high dose (Fig. 3). TS exposure stimulated membrane integrity in maturing and mature stages (Fig. 2), whereas effects from DHTS 

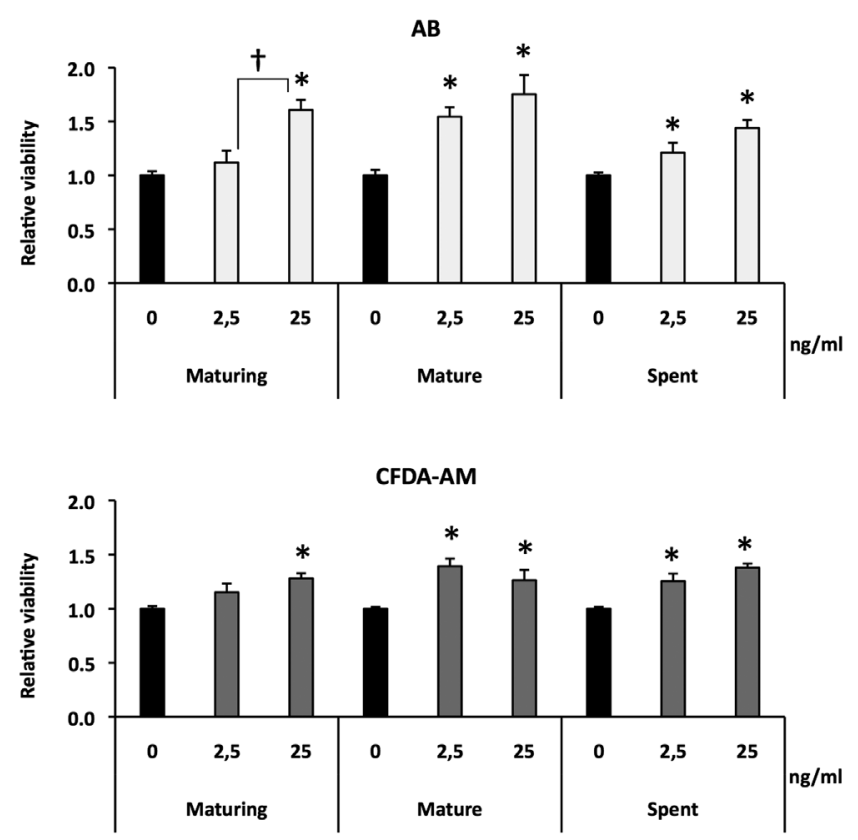

Figure 1 Viability in Atlantic cod pituitary cells after 7 days of primary culture and $72 \mathrm{~h}$ of estradiol exposure, in terms of mitochondrial activity $(\mathrm{AB})$ and membrane integrity (CFDA-AM). Data are presented as mean fold-change relative to solvent control \pm S.E.M. $(n=8-12)$. Asterisk indicates statistical difference from control, while dagger indicates statistical difference between doses $(P<0.05)$.

was seen only during the former with this parameter. No effect on viability was detected from androgen treatment on cells from spent fish.
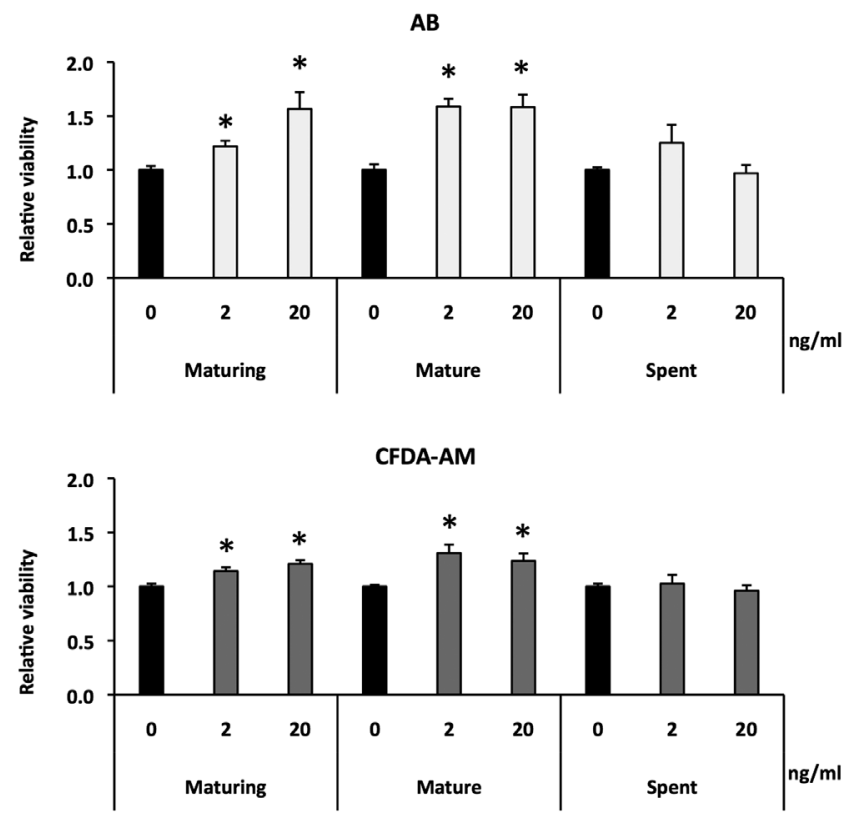

Figure 2 Viability in Atlantic cod pituitary cells after 7 days of primary culture and $72 \mathrm{~h}$ of TS exposure, in terms of mitochondrial activity $(\mathrm{AB})$ and membrane integrity (CFDA-AM). Data are presented as mean fold-change relative to solvent control \pm S.E.M. $(n=8-12)$. Asterisk indicates statistical difference from control $(P<0.05)$.

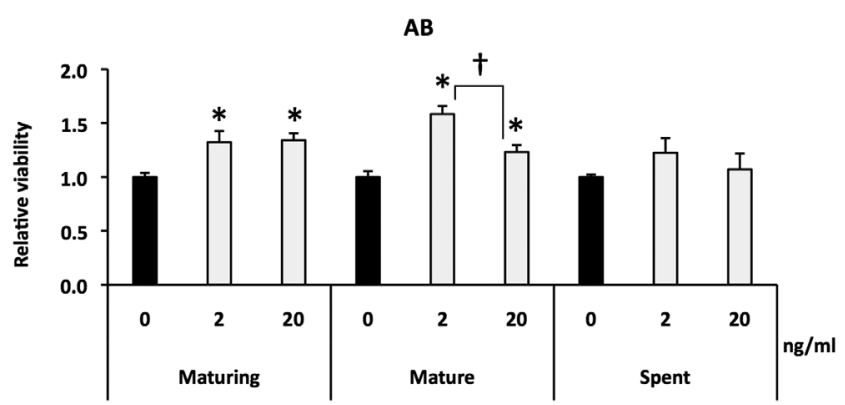

CFDA-AM

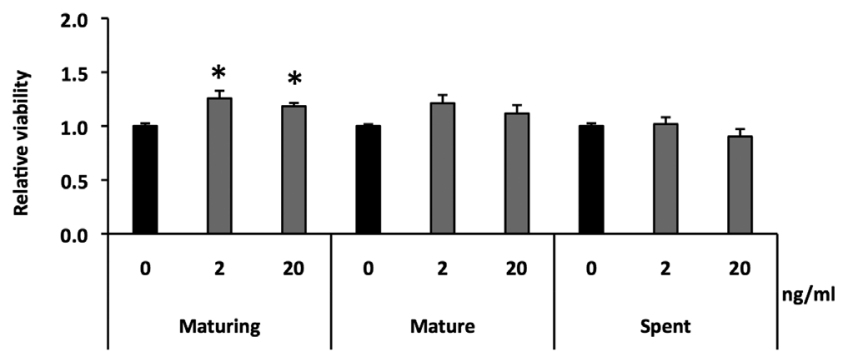

Figure 3 Viability in Atlantic cod pituitary cells after 7 days of primary culture and $72 \mathrm{~h}$ of DHTS exposure, in terms of mitochondrial activity $(A B)$ and membrane integrity (CFDA-AM). Data are presented as mean fold change relative to solvent control \pm S.E.M. $(n=8-12)$. Asterisk indicates statistical difference from control, while dagger indicates statistical difference between doses $(P<0.05)$.

\section{Cod pituitary gene expression after 7 days of primary culture}

\section{Gene expression in individual gonadotropes}

In order to identify which Gnrh receptors (Gnrhr) are expressed in cod gonadotropes, cytosol from individual non-exposed fshb- or lhb-expressing cells from mature fish was analyzed by single-cell qPCR. Ten fshb-expressing and $10 \mathrm{lhb}$-expressing cells were assessed, and 7 of each cell type expressed gnrhr2a. In the remaining cells, no gnrhr expression was detected. Of the 7 gnrhr2a-positive cells, three also expressed gnrhr1b, both in $f_{s h b}$ - and Ihb-expressing cells (Fig. 4), meaning both isoforms are expressed in individual gonadotropes. However, gnrhr1b expression was low and close to the detection limit of the qPCR assay $(\mathrm{Cq}$ values from 35 to 38). Thus, gnrhr2a seems to be the predominant receptor in both gonadotrope cell types, at least during spawning season (Cq values from 32 to 34).

\section{Gene expression in steroid-exposed cells}

Following $72 \mathrm{~h}$ of steroid exposure, gene expression of gonadotropin $\beta$-subunits and two Gnrhr's in the pituitary cells was determined by qPCR (Figs 5, 6 and 7). In general, steroid treatment had differential effects on gene expression, dependent on the type of steroid, target gene and time of year. Common for all three steroids was that 

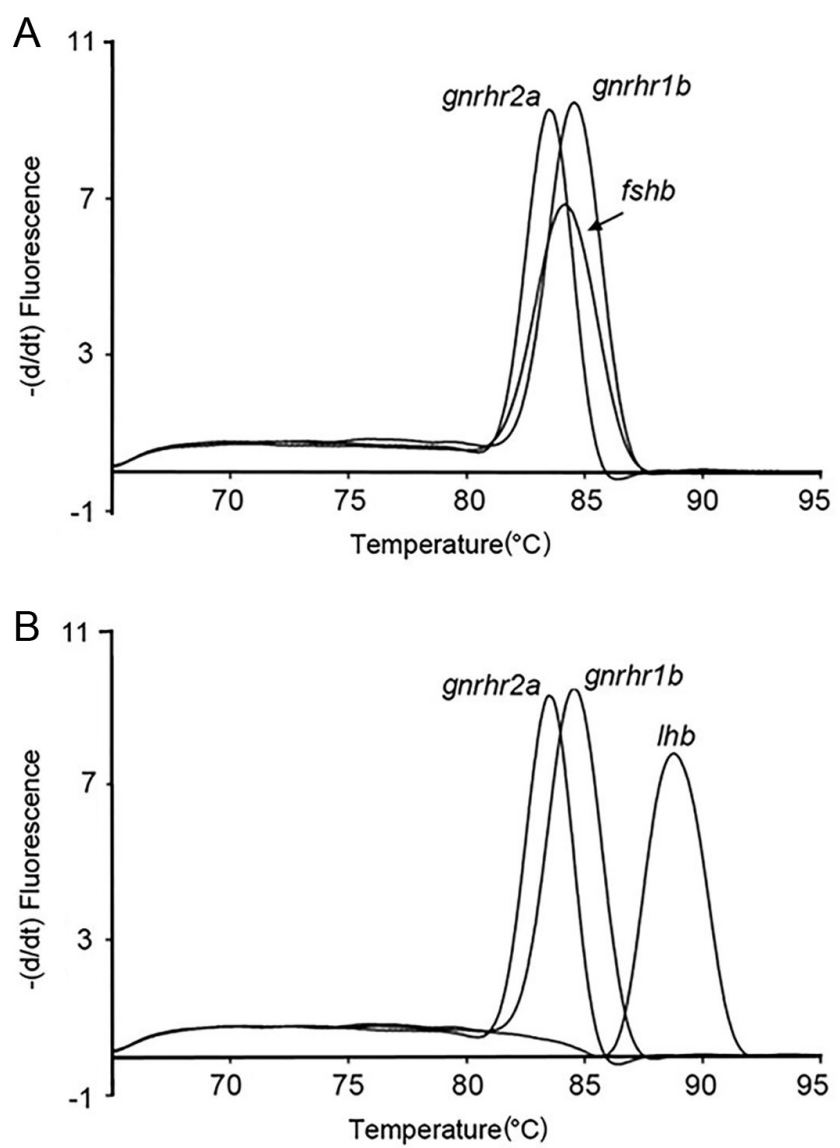

Figure 4 Transcripts of gnrhr $1 b$ and gnrhr2a in $f$ shb- and $/ h b$ expressing cells in Atlantic cod. Melting curve analysis of qPCR products from a single-cell was performed directly after the qPCR and plotted as the negative change in fluorescence per time as a function of temperature. Each qPCR product is reflected in a specific melting peak in the melting curve analysis. Expression of both gnrhr $1 b$ and gnrhr2a was detected in (A) fshb-expressing cells and (B) Ihb-expressing cells.

gnrhr2a transcript levels showed the strongest treatment response, while, regardless of season, no response on gnrhr $1 b$ expression was observed.

In more detail, a significant increase in gnrhr2a levels was seen after high-dose E2 $(25 \mathrm{ng} / \mathrm{mL})$ exposure in cells from mature fish, while both E2 doses increased gnrhr2a expression during the spent stage (Fig. 5). Gonadotropin transcript levels were mainly unaffected by E2, with the exception of a significant increase in $f s h b$ expression following high-dose treatment in mature fish. A similar trend was observed with the expression of $/ h b(P=0.08)$.

The effects from TS exposure on gnrhr2a expression were seasonally dependent (Fig. 6). During maturation, no effects were seen, whereas the high dose $(20 \mathrm{ng} / \mathrm{mL})$ stimulated expression during the mature stage. Interestingly, in cells from spent fish, the effect of the low TS dose $(2 \mathrm{ng} / \mathrm{mL})$ on gnrhr2a expression was significantly different from both control and the high TS dose. A similar pattern was seen with fshb, where the low dose stimulated expression during maturation, while the high dose had no effect. During the mature stage, there were no observed effects on $f s h b$ expression, while transcript levels decreased following high-dose TS treatment in cells from spent fish. TS exposure had no statistically significant effects on thb expression, although a decreasing trend was observed during the spent stage $(P=0.13)$.

While E2 and TS stimulated gnrhr2a expression during mature and spent stages, DHTS affected gnrhr2a only in cells from maturing fish (Fig. 7), with the highdose $(20 \mathrm{ng} / \mathrm{mL})$ exposure increasing expression. For gonadotropin gene expression, an effect from DHTS treatment was seen in cells from maturing fish. While the low DHTS dose $(2 \mathrm{ng} / \mathrm{mL})$ resulted in increased expression levels of both fshb and lhb, the high DHTS dose only significantly increased lhb expression levels, although fshb expression levels were also increased, but not significantly $(P=0.067)$.

\section{Discussion}

Gonadotropes are important regulators of reproduction in vertebrates and are themselves subject to regulation from both hypothalamic input and systemic feedback. Using primary pituitary cell cultures as model system, this study describes the effects of sex steroid (E2, TS and DHTS) exposure (72 h) on cell viability and gene expression of gonadotropin $\beta$-subunits ( $f_{s} h b$ and $/ h b$ ) and two Gnrh receptors (gnrhr1b and gnrhr2a) during three stages of sexual maturity in Atlantic cod. In addition, it demonstrates that both $f_{s} h b$ - and Ihb-producing gonadotropes can co-express two Gnrh receptor genes, gnrhr1b and gnrhr2a.

\section{Cell viability}

Very few studies have investigated pituitary cell viability after steroid exposure in fish, which is somewhat surprising as in most in vitro studies steroids are generally solubilized using solvents such as ethanol $(\mathrm{EtOH})$ or dimethyl sulfoxide (DMSO), chemicals known to elicit deleterious effects on the health and properties of cultured cells (Baker \& Kramer 1999, Santos et al. 2002). In this study, steroids were dissolved in $\mathrm{EtOH}$ to a final exposure concentration of $0.2 \%$. This concentration did not affect gene expression of any gene analyzed, but did negatively affect the viability of the cells as compared to those exposed to EtOHfree media, both in terms of metabolic activity and membrane integrity. Consequently, all steroid exposed cells were compared to that of the solvent control. The negative effects on cell viability seen from $\mathrm{EtOH}$ were generally reversed with the addition of steroids. One proposed mechanism for the non-genomic effects of steroids is intercalation into the phospholipid bilayer, 
Sex steroid feedback in Atlantic cod

587

Estradiol

fsh

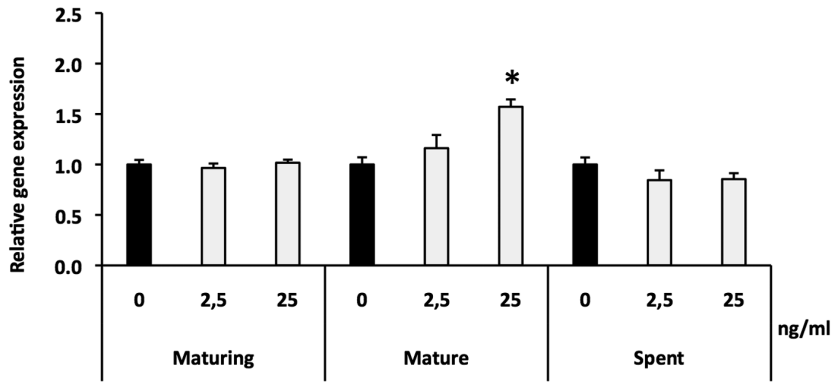

gnrhr1b

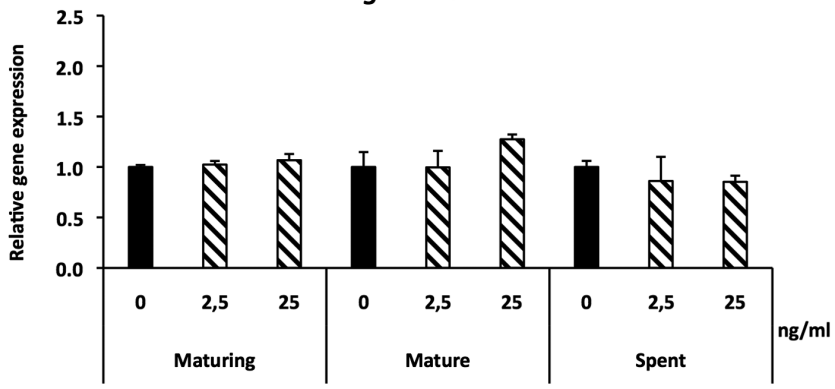

lh

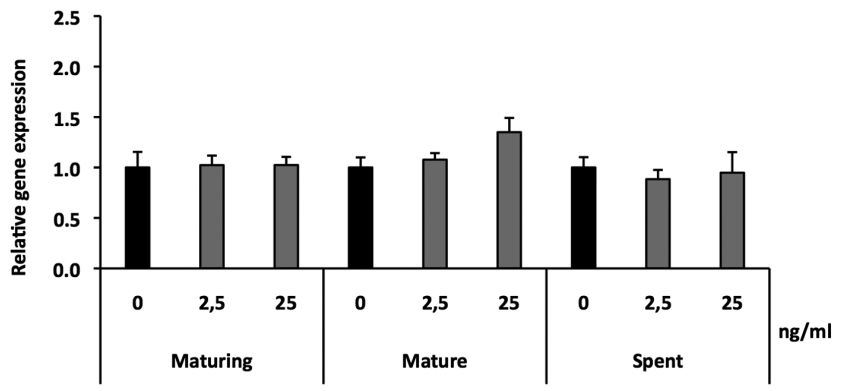

gnrhr2a

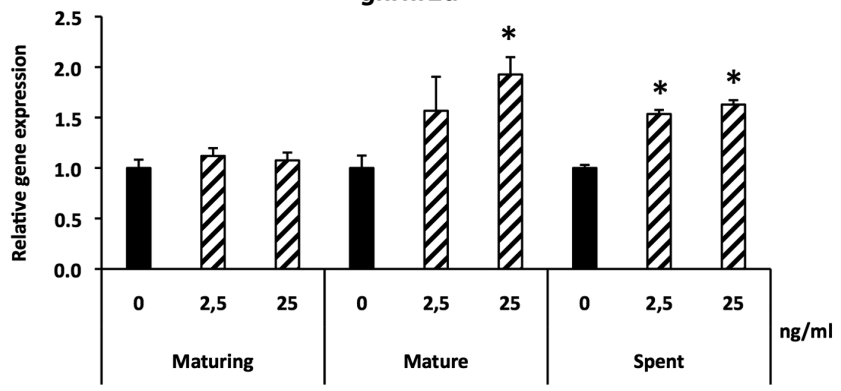

Figure 5 Gene expression in Atlantic cod pituitary cells after $72 \mathrm{~h}$ of estradiol exposure in vitro, presented as mean fold-change relative to solvent control \pm S.E.M. $(n=6-12)$. Asterisks indicate statistical significant difference from control $(P<0.05)$.

TS

fsh b

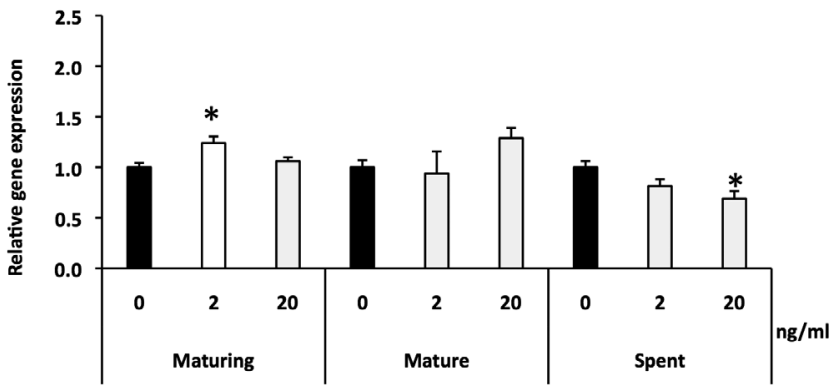

gnrhr1b

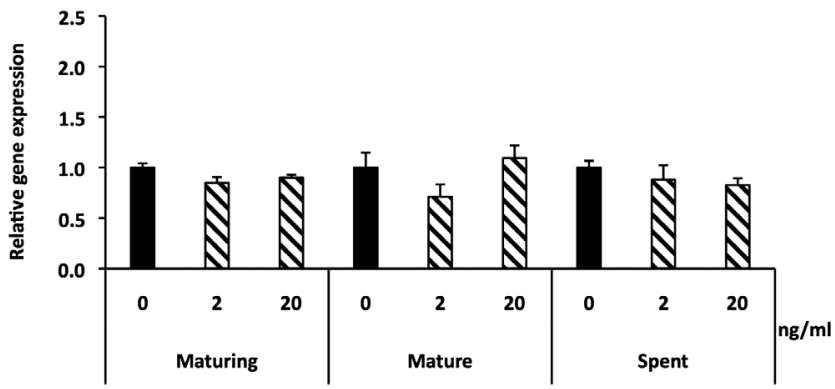

Ihs

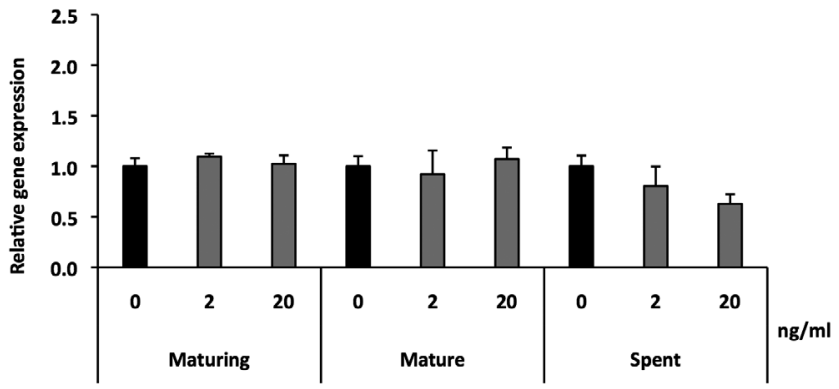

gnrhr2a

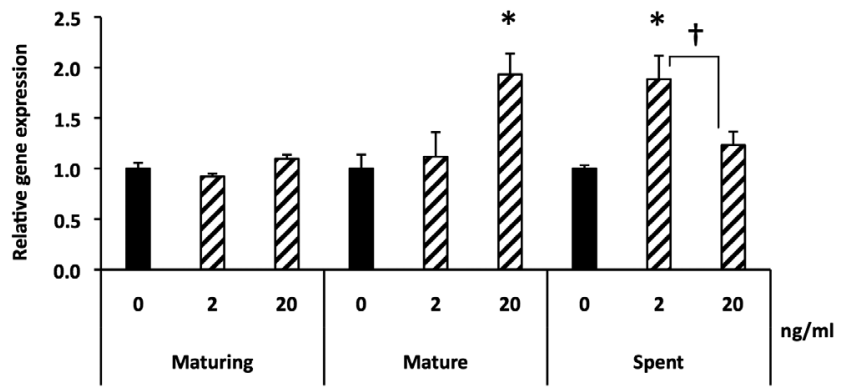

Figure 6 Gene expression in Atlantic cod pituitary cells after $72 \mathrm{~h}$ of TS exposure in vitro, presented as mean fold-change relative to solvent control \pm S.E.M. $(n=6-12)$. Asterisk indicates statistical difference from control, while dagger indicates statistical difference between doses $(P<0.05)$.

www.reproduction-online.org

Reproduction (2017) 154 581-594

Downloaded from Bioscientifica.com at $04 / 26 / 2023$ 12:29:21 AM

via free access 

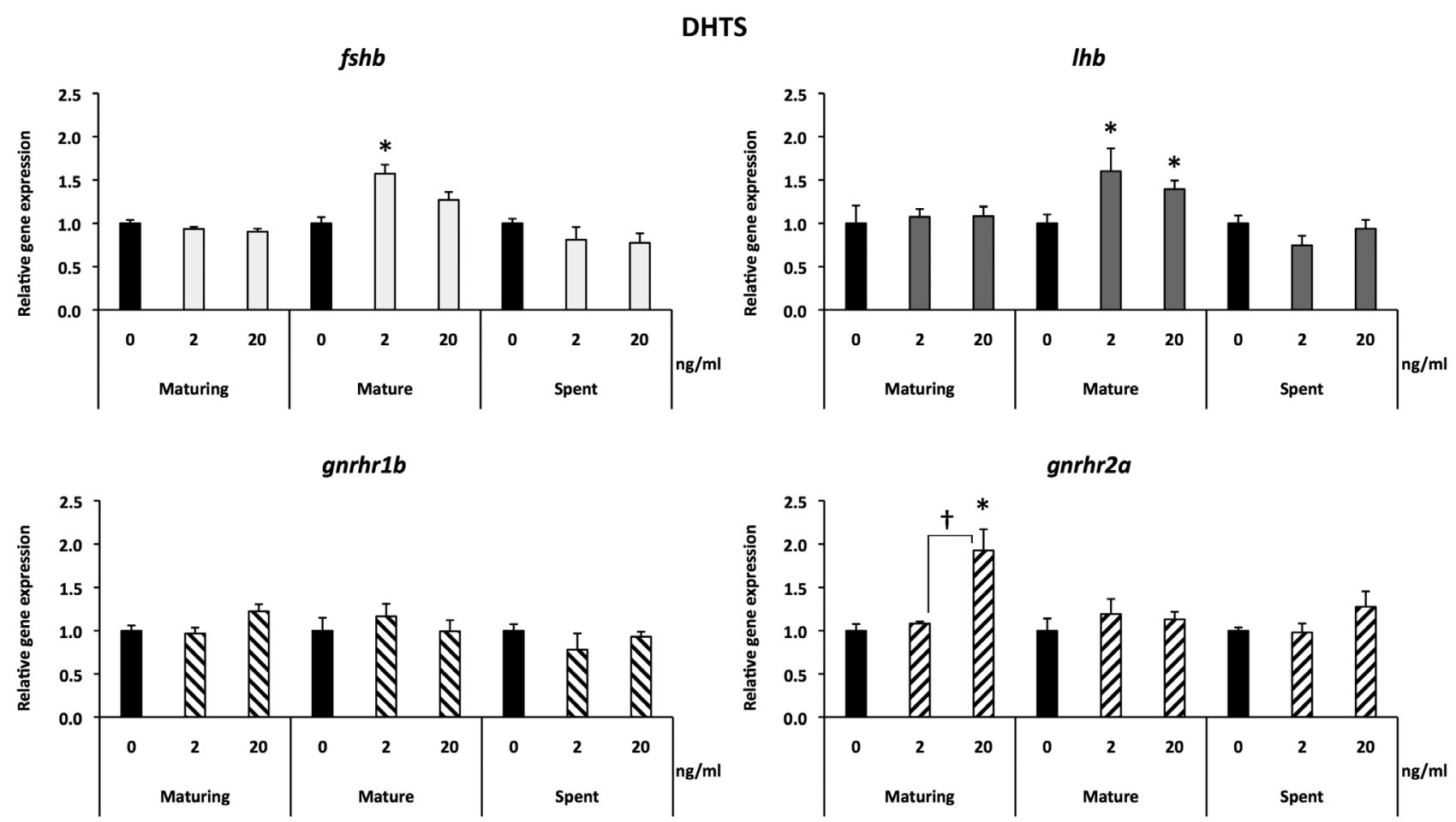

Figure 7 Gene expression in Atlantic cod pituitary cells after $72 \mathrm{~h}$ of DHTS exposure in vitro, presented as mean fold change relative to solvent Control \pm S.E.M. $(n=6-12)$. Asterisk indicates statistical difference from control, while dagger indicates statistical difference between doses $(P<0.05)$.

introducing structural and functional alterations of the cell membrane (Golden et al. 1998, Falkenstein et al. 2000, Whiting et al. 2000). In the present study, using physiological sex steroid concentrations, no negative effects on membrane integrity in cod pituitary cells was observed. This was not surprising, as membrane perturbations such as fluidity changes and leakage occur mainly at high, non-physiological, concentrations (Clarke et al. 1990, Shivaji \& Jagannadham 1992). However, some differential effects were seen. While all steroids generally stimulated membrane integrity, E2 did so regardless of maturational state. While TS had no effect on pituitary cells from spent fish, DHTS had no effect on cells from both spent and mature fish. A similar pattern was evident from the metabolic activity assay. E2 stimulated cell metabolism at all three reproductive stages, while the androgens stopped being stimulatory in cells from the spent stage. This strongly implies that for androgens, there is a seasonal effect in terms of both membrane integrity and cellular metabolism. In spent fish, the endocrine activity of gonadotropes is low, with fshb and Ihb synthesis being at its lowest level in the reproductive cycle (Mittelholzer et al. 2009). Although the present study was performed on all pituitary cell types and not just gonadotropes, it is tempting to speculate that there might be an association between gonadotropic endocrine activity and the androgen interplay with the plasma membrane and cellular metabolism in spent fish.

\section{Gonadotropin expression}

With the exception of the goldfish (Carassius auratus), that has been thoroughly studied (Kobayashi et al. 1989, 2000, Huggard et al. 1996, Sohn et al. 1998, 2001, Huggard-Nelson et al. 2002), most studies on teleost steroid feedback have been on single or total spawners. Tables 2, 3, 4 and 5 summarize studies on steroid effects on gonadotropin $\beta$-subunit mRNA synthesis in multibatch and asynchronous spawners (Tables 2, 3, 4 and 5: Hermaphrodite species are omitted; Tables 4 and 5: Studies using gonadectomized fish are omitted due to possible pain/stress interaction with reproduction). Common for the in vitro studies is that steroid exposure leads to no or stimulating effects on gonadotropin transcript levels, indicating that positive feedback can occur through mechanisms directly at the pituitary level. Inhibiting effects from steroids on gonadotropin transcripts have rarely been observed in vitro, but in the male African catfish (Clarias gariepinus) 24-h sex steroid (11-ketotestosterone (11-KTS), TS or E2) exposure inhibited Ihb expression (Rebers et al. 2000). In the present study, TS inhibited fshb expression in spent cod. There are therefore likely, at least in some species, mechanisms that facilitate negative feedback directly at the pituitary level also.

Due to high levels of aromatase, the enzyme complex that converts TS to E2, in the brain and pituitary of teleosts 


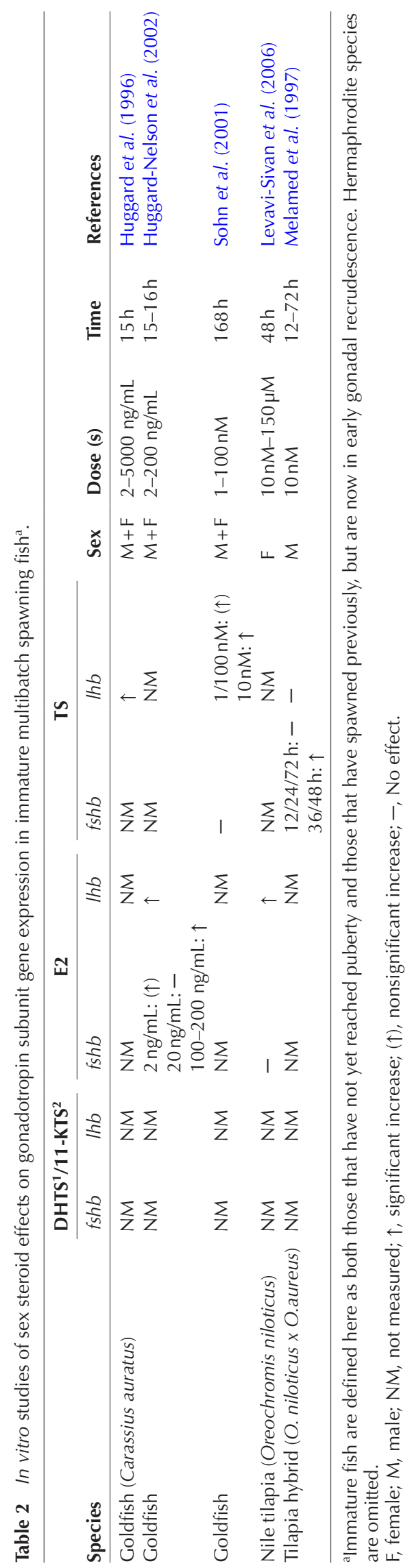

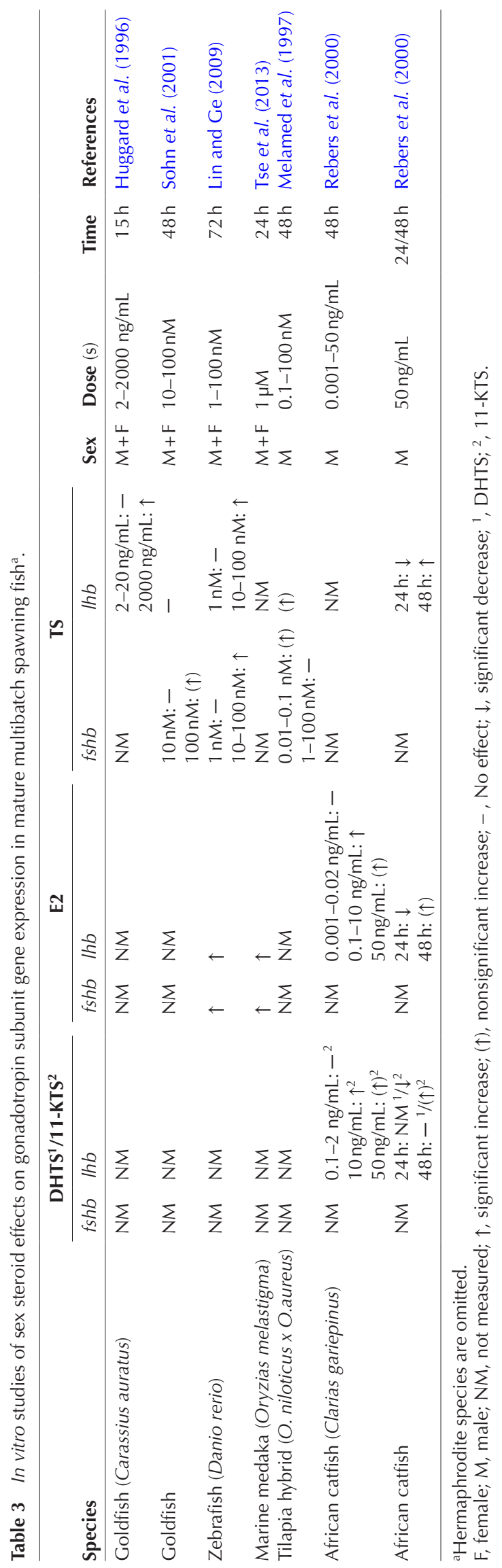

Reproduction (2017) 154 581-594 


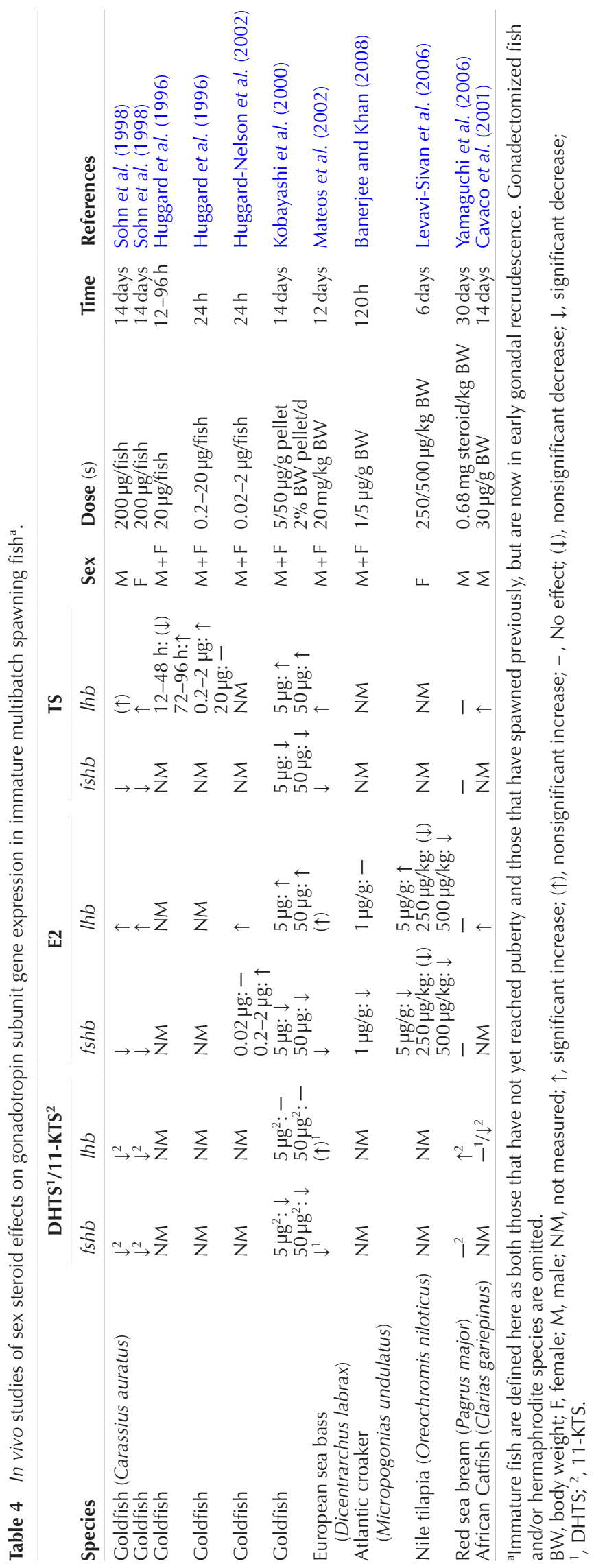

(Diotel et al. 2010), effects from TS exposure might occur through both androgenic and estrogenic mechanisms. The level of brain aromatase gene expression and enzyme activity is itself modulated by steroids and has been shown to fluctuate with the reproductive stage and season in several species (Andersson et al. 1988, Pasmanik \& Callard 1988a, Gonzalez \& Piferrer 2003, Diotel et al. 2010). Hence, the amount of TS aromatization might vary and many studies on potential sex steroid feedback therefore include a nonaromatizable androgen to distinguish between actions mediated through estrogen receptors (Er) and androgen receptors (Ar). Despite 11-KTS being non-aromatizable and generally the most important teleost androgen, DHTS was chosen as the non-aromatizable androgen in this study, in part because this androgen has a high binding affinity for the $\operatorname{Ar}$ (Sperry \& Thomas 1999, Jørgensen et al. 2007), and partly because it is often used in studies to demonstrate androgen effects (Martyniuk et al. 2013). Although the presence, let alone the biological activity, of DHTS has not been demonstrated in most teleosts, its synthesis and plasma levels has been reported in both male and female fathead minnow (Pimephales promelas) (Margiotta-Casaluci et al. 2013). In another species, the urohaze-goby (Glossogobius olivaceus), DHTS was the main product of in vitro steroidogenesis in testes tissue (Asahina et al. 1985). In addition, enzymatic activity of $5-\alpha$ reductase, the enzyme that converts TS to DHTS, has been demonstrated in different tissues, including the brain and pituitary, in several teleost species (Pasmanik \& Callard 1988a, Latz \& Reinboth 1993, MargiottaCasaluci et al. 2013), so it is likely that DHTS plays a biological role not yet described in teleosts. In the present study, DHTS stimulated fshb expression in cells from mature cod, which, to our knowledge, is the first time effects on $f_{s} h b$ expression from a non-aromatizable androgen have been demonstrated in vitro in a multibatch spawner. Furthermore, DHTS, but not T, affected thb expression. This result is in contrast to a study performed on mature male African catfish, where a relatively high dose $(50 \mathrm{ng} / \mathrm{mL})$ of DHTS had no effect on $/ \mathrm{hb}$ expression in vitro, whereas a similar dose of TS did, presumably following aromatization to E2 (Rebers et al. 2000). In Atlantic cod, high E2 dose $(20 \mathrm{ng} / \mathrm{mL})$ had a stimulatory trend on $/ h b$ transcription in mature fish, but this result was not statistically significant. While TS had no effect on thb levels, all steroids affected $f s h b$ expression at some point during the reproductive cycle, indicating that both estrogenic and androgenic mechanisms are involved in its regulation at the pituitary level in the cod. In a recent study on Atlantic cod, Nagasawa and coworkers (2014) demonstrated a seasonal variation in gonadal $\mathrm{Er}$ and $\mathrm{Ar}$ gene expression levels. To our knowledge, there is no available data regarding $\mathrm{Er} / \mathrm{Ar}$ seasonal variation at the pituitary level in cod, although an earlier study reported changes in pituitary Er transcript levels over the reproductive cycle in the largemouth 
Table 5 In vivo studies of sex steroid effects on gonadotropin subunit gene expression in mature multibatch spawning fisha

\begin{tabular}{|c|c|c|c|c|c|c|c|c|c|c|}
\hline \multirow[b]{2}{*}{ Species } & \multicolumn{2}{|c|}{ DHTS $^{1 / 11-K_{T S}}{ }^{2}$} & \multicolumn{2}{|c|}{ E2 } & \multicolumn{2}{|c|}{ TS } & \multirow[b]{2}{*}{ Sex } & \multirow[b]{2}{*}{ Dose $(s)$} & \multirow[b]{2}{*}{ Time } & \multirow[b]{2}{*}{ References } \\
\hline & $f_{s h b}$ & Ihb & $f_{s h b}$ & Ihb & $f_{s h b}$ & Ihb & & & & \\
\hline Goldfish (Carassius auratus) & -2 & $(\uparrow)^{2}$ & - & $\uparrow$ & - & $(\uparrow)$ & M & $200 \mu \mathrm{g} / \mathrm{fish}$ & 14 days & Sohn et al. (1998) \\
\hline Goldfish & $(\uparrow)^{2}$ & -2 & $(\downarrow)$ & - & - & - & $\mathrm{F}$ & $200 \mu \mathrm{g} /$ fish & 14 days & Sohn et al. (1998) \\
\hline Goldfish & NM & NM & NM & NM & NM & $\uparrow$ & $M+F$ & $0.02-20 \mu \mathrm{g} /$ fish & $24 \mathrm{~h}$ & Huggard et al. (1996) \\
\hline $\begin{array}{l}\text { African Catfish } \\
\quad \text { (Clarias gariepinus) }\end{array}$ & NM & $\uparrow^{2}$ & NM & NM & NM & NM & M & 10,20 and $100 \mu \mathrm{g} / \mathrm{kg}$ BW & 5 days & Rebers et al. (1997) \\
\hline
\end{tabular}

${ }^{\mathrm{a}}$ Gonadectomized fish and/or hermaphrodite species are omitted.

BW, body weight; F, female; $M$, male; NM, not measured; $\uparrow$, significant increase; $(\uparrow)$, nonsignificant increase; - , No effect; $(\downarrow)$, nonsignificant decrease; ${ }^{1}$, DHTS; ${ }^{2}, 11-$ KTS.

bass (Micropterus salmoides) (Martyniuk et al. 2009). In the current study, the steroids had differential effects on gonadotropin subunits expression at the different reproductive stages. Fluctuations in Er/Ar levels could change tissue sensitivity or responsiveness to estrogens/ androgens and might serve as a possible explanation to this observation. Furthermore, as mixed sex cultures were used in these experiments, no information about potential sex-dependent regulation can be provided. It is possible that results from one sex could mask results from the other. Potential male vs female differences regarding both gonadotropin steroid sensitivity and $\mathrm{Er} / \mathrm{Ar}$ levels through the reproductive cycle would be interesting and relevant topics for future studies in Atlantic cod.

\section{Gonadotropin-releasing hormone receptor expression}

In cell cultures prepared from intact pituitaries, all pituitary cell types, not just the gonadotropes, are present. Previously, Gnrhr gene expression or protein has been demonstrated in gonadotropes, somatotropes (ST), lactotropes, thyrotropes (TT), melanotropes, corticotropes (CT) and somatolactotropes (SLT) (Illing et al. 1999, Parhar et al. 2002, 2005, Flanagan et al. 2007). In Nile tilapia (Oreochromis niloticus), Parhar and coworkers (2005) conducted a study examining receptor expression in individual pituitary cells. They showed that mRNA of receptors phylogenetically close to gnrhr $1 b$ was expressed in all cells types except TT, SLT (mature fish) and CT (immature fish). Similarly, mRNA of receptors closely related to gnrhr2a was detected in all cell types except immature fish TT and CT cells. The same study also showed that individual cells could concurrently express several isoforms of Gnrhr and that both $f_{s} h b$ and $/ h b$-producing gonadotropes expressed both gnrhr1b and gnrhr2a. In the present study, it was demonstrated that this also is true in Atlantic cod, with co-expression of both receptors detected in $30 \%$ of the gonadotropes investigated. While this points toward a role for both receptors in gonadotropin regulation, in both $f_{s} h b$ - and Ihb-expressing cells, gnrhr2a was clearly the predominant receptor. In a study on Gnrhr gene expression over the reproductive cycle in female Atlantic cod, Hildahl and coworkers (2011) showed that, in whole pituitary samples, only gnrhr2a isoform expression levels followed the same profile as the GSI, and was significantly upregulated during periods of reproductive activity. Even though the observed expression pattern could not be confined to only gonadotropes, these results indicate that gnrhr2a is the main receptor mediating gonadotropin expression in cod.

In teleosts, as well as mammals, steroid treatment has been shown to modify pituitary responsiveness to Gnrh and regulate Gnrhr mRNA abundance (QuinonesJenab et al. 1996, Cowley et al. 1998, Yen et al. 2002, Levavi-Sivan et al. 2006, Lin et al. 2010). In the current study, gnrhr1b showed no, whereas gnrhr2a showed strong, sensitivity to steroid exposure. All sex steroids tested were able to stimulate the expression of gnrhr2a, which would, assuming its translation into functional protein, increases the sensitivity of gonadotropes to Gnrh stimulation and acts as a direct route for a positive feedback at the pituitary level. However, the mechanisms through which steroids affect gnrhr2a expression is not clear, as the stimulation occurred at different times of the year dependent on the steroid. During maturation, gnrhr2a transcripts were upregulated by DHTS exposure, while at later stages, DHTS did not affect its expression. Conversely, no effect was seen from E2 or TS during maturation, but both hormones stimulated gnrhr2a transcription in cells from mature and spent fish. In general, a close correlation exists between circulating steroid levels and GSI in Atlantic cod, with low plasma levels during early gonadal recrudescence, increasing during maturation, peaking at spawning, before declining rapidly in spent fish (Dahle et al. 2003). The steroid sensitivity of gnrhr2a does thus not correlate with circulating steroid levels. As with the gonadotropin regulation, seasonal and differential regulation or location of $\mathrm{Ar} / \mathrm{Er}$ and their respective isoforms might be one explanation to this (Pasmanik \& Callard 1988b, Harbott et al. 2007).

In the pituitary primary cultures used in the present study, control levels of gnrhr1b expression (data not shown) were quite stable over the reproductive cycle except for a small decrease during spawning season, and no effect on its transcription was seen following steroid exposure. In individual cells from mature fish, single-cell qPCR demonstrated that while gnrhr $1 b$ was co-expressed with gnrhr2a in the gonadotropes, the transcript levels 
were low and sometimes undetectable. Taken together, these results indicate that, in Atlantic cod, Gnrhr1b is not a part of the sex steroid feedback mechanism at the pituitary level and its gene expression is more abundant in other pituitary cell types than gonadotropes. In cod, as in many other teleosts, somatic growth rate is low during times of gonadal growth and spawning (Hansen et al. 2001). The growth rate is mediated mainly through the somatotropic axis (Dai et al. 2015), where growth hormone (Gh) production may be stimulated by Gnrh (Marchant et al. 1989). Since gnrhr1b transcript levels decreased during spawning season in control cells and have been demonstrated in STs in other species (Flanagan et al. 2007), a tempting hypothesis for future studies is that this receptor is involved in Gh regulation.

\section{Conclusions}

In the present study, it was demonstrated that sex steroids (E2, TS and DHTS) stimulate cell viability and have the ability to directly affect transcript levels of gonadotropins and two Gnrhr orthologues in the Atlantic cod pituitary. Cell viability was not correlated to gene expression, as steroids induced overall stimulating effects on metabolic activity and membrane integrity, while transcript levels had more seasonally dependent patterns. Co-transcription of gnrhr1b and gnrhr2a was confirmed to both $f s h b$ - and $/ h b$ - expressing gonadotropes using single-cell qPCR, with gnrhr2a clearly being most prominently expressed. While steroid exposure had no effect on gnrhr1b expression, all steroids stimulated gnrhr2a levels at some stage in the reproductive cycle. These results point to Gnrhr2a being the main modulator of gonadotropin regulation in Atlantic cod, and that regulation of its gene expression level might function as a direct mechanism for positive steroid feedback at the pituitary level. The expression of fshb showed greater steroid sensitivity than that of $/ h b$ and was affected by all steroids at some reproductive stage, while only DHTS was able to affect $/ h b$ expression. The mechanisms behind the differential steroid sensitivity is not clear, but might be due to different hormonal regulatory elements in the promoter region of the genes, the level/existence of $\mathrm{Er} / \mathrm{Ar}$ in cell types that express the individual genes or that these levels vary with season.

\section{Supplementary data}

This is linked to the online version of the paper at http://dx.doi.org/10.1530/REP-17-0208.

\section{Declaration of interest}

The authors declare that there is no conflict of interest that could be perceived as prejudicing the impartiality of the research reported.

\section{Funding}

This study was supported by the Research Council of Norway (Grants no. 184851 and 191825), and by the Norwegian University of Life Sciences.

\section{Acknowledgements}

The authors would like to thank Ketil Hylland, Ørjan Karlsen, and the crew at Trygve Braarud, for help requiring cod, Mazyar Yazdani for guidance with the plate reader, Stig Larsen for valuable discussions of statistical analyses, Ellen Dahl for advice regarding steroid handling and lan Mayer for proofreading the manuscript.

\section{References}

Almeida FFL, Taranger GL, Norberg B, Karlsen Ø, Bogerd J \& Schulz RW 2009 Photoperiod-modulated testis maturation in Atlantic cod (Gadus morhua, L.). Biology of Reproduction 80 631-640. (doi:10.1095/ biolreprod.108.071340)

Andersson E, Borg B \& Lambert JGD 1988 Aromatase-activity in brain and pituitary of immature and mature Atlantic salmon (Salmo salar L) parr. General and Comparative Endocrinology 72 394-401. (doi:10.1016/0016-6480(88)90161-X)

Aroua S, Weltzien F-A, Le Belle N \& Dufour S 2007 Development of real-time RT-PCR assays for eel gonadotropins and their application to the comparison of in vivo and in vitro effects of sex steroids. General and Comparative Endocrinology 153 333-343. (doi:10.1016/j. ygcen.2007.02.027)

Asahina K, Suzuki K, Aida K, Hibiya T \& Tamaoki B 1985 Relationship between the structures and steroidogenic functions of the testes of the urohaze-goby (Glossogobius olivaceus). General and Comparative Endocrinology 57 281-292. (doi:10.1016/0016-6480(85)90273-4)

Baker RC \& Kramer RE 1999 Cytotoxicity of short-chain alcohols. Annual Review of Pharmacology and Toxicology 39 127-150. (doi:10.1146/ annurev.pharmtox.39.1.127)

Banerjee A \& Khan IA 2008 Molecular cloning of FSH and LH beta subunits and their regulation by estrogen in Atlantic croaker. General and Comparative Endocrinology 155 827-837. (doi:10.1016/j. ygcen.2007.09.016)

Billard R 1978 Testicular feedback on hypothalamo-pituitary axis in rainbow trout (Salmo gairdneri R.). Annales De Biologie Animale Biochimie Biophysique 18 813-818. (doi:10.1051/rnd:19780509)

Bopp SK \& Lettieri T 2008 Comparison of four different colorimetric and fluorometric cytotoxicity assays in a zebrafish liver cell line. BMC Pharmacology 8 8. (doi:10.1186/1471-2210-8-8)

Borg B, Antonopoulou E, Mayer I, Andersson E, Berglund I \& Swanson P 1998 Effects of gonadectomy and androgen treatments on pituitary and plasma levels of gonadotropins in mature male Atlantic salmon, Salmo salar, parr-positive feedback control of both gonadotropins. Biology of Reproduction 58 814-820. (doi:10.1095/biolreprod58.3.814)

Brander KM 1994 The location and timing of cod spawning around the British Isles. Ices Journal of Marine Science 51 71-89. (doi:10.1006/ jmsc.1994.1007)

Cavaco JEB, van Baal J, van Dijk W, Hassing GAM, Goos HJT \& Schulz RW 2001 Steroid hormones stimulate gonadotrophs in juvenile male African catfish (Clarias gariepinus). Biology of Reproduction 64 1358-1365. (doi:10.1095/biolreprod64.5.1358)

Clarke R, Vandenberg HW \& Murphy RF 1990 Reduction of the membrane fluidity of human breast-cancer cells by tamoxifen and 17-beta-estradiol Journal of the National Cancer Institute 82 1702-1705. (doi:10.1093/ jnci/82.21.1702)

Cowley MA, Rao A, Wright PJ, Illing N, Millar RP \& Clarke IJ 1998 Evidence for differential regulation of multiple transcripts of the gonadotropin releasing hormone receptor in the ovine pituitary gland; effect of estrogen. Molecular and Cellular Endocrinology 146 141-149. (doi:10.1016/S0303-7207(98)00162-2) 
Dahle R, Taranger GL, Karlsen Ø, Kjesbu OS \& Norberg B 2003 Gonadal development and associated changes in liver size and sexual steroids during the reproductive cycle of captive male and female Atlantic cod (Gadus morhua L.). Comparative Biochemistry and Physiology A-Molecular and Integrative Physiology 136 641-653. (doi:10.1016/ s1095-6433(03)00215-0)

Dai XY, Zhang W, Zhuo ZJ, He JY \& Yin Z 2015 Neuroendocrine regulation of somatic growth in fishes. Science China-Life Sciences 58 137-147. (doi:10.1007/s11427-015-4805-8)

Diotel N, Le Page Y, Mouriec K, Tong S-K, Pellegrini E, Valliant C, Anglade I, Brion F, Pakdel F, Chung B-c et al. 2010 Aromatase in the brain of teleost fish: expression, regulation and putative functions. Frontiers in Neuroendocrinology 31 172-192. (doi:10.1016/j.yfrne.2010.01.003)

Dufour S, Sebert ME, Weltzien FA, Rousseau K \& Pasqualini C 2010 Neuroendocrine control by dopamine of teleost reproduction. Journal of Fish Biology 76 129-160. (doi:10.1111/j.1095-8649.2009.02499.x)

Falkenstein E, Tillmann HC, Christ M, Feuring M \& Wehling M 2000 Multiple actions of steroid hormones - a focus on rapid, nongenomic effects. Pharmacological Reviews 52 513-555.

Flanagan CA, Chen CC, Coetsee M, Mamputha S, Whitlock KE, Bredenkamp N, Grosenick L, Fernald RD \& Illing N 2007 Expression, structure, function, and evolution of gonadotropin-releasing hormone $(\mathrm{GnRH})$ receptors GnRH-R1(SHS) and GnRH-R2(PEY) in the teleost, Astatotilapia burtoni. Endocrinology 148 5060-5071. (doi:10.1210/en.2006-1400)

Golden GA, Mason PE, Rubin RT \& Mason RP 1998 Biophysical membrane interactions of steroid hormones: a potential complementary mechanism of steroid action. Clinical Neuropharmacology 21 181-189.

Gonzalez A \& Piferrer F 2003 Aromatase activity in the European sea bass (Dicentrarchus labrax L.) brain. Distribution and changes in relation to age, sex, and the annual reproductive cycle. General and Comparative Endocrinology 132 223-230. (doi:10.1016/S0016-6480(03)00086-8)

Hansen T, Karlsen $\varnothing$, Taranger GL, Hemre GI, Holm JC \& Kjesbu OS 2001 Growth, gonadal development and spawning time of Atlantic cod (Gadus morhua) reared under different photoperiods. Aquaculture 203 51-67. (doi:10.1016/S0044-8486(01)00610-X)

Harbott LK, Burmeister SS, White RB, Vagell M \& Fernald RD 2007 Androgen receptors in a cichlid fish, Astatotilapia burtoni: structure, localization, and expression levels. Journal of Comparative Neurology 504 57-73. (doi:10.1002/cne.21435)

Hildahl J, Sandvik GK, Edvardsen RB, Norberg B, Haug TM \& Weltzien FA 2011 Four gonadotropin releasing hormone receptor genes in Atlantic cod are differentially expressed in the brain and pituitary during puberty. General and Comparative Endocrinology 173 333-345. (doi:10.1016/j. ygcen.2011.06.002)

Hodne K, Haug TM \& Weltzien FA 2010 Single-cell qPCR on dispersed primary pituitary cells -an optimized protocol. BMC Molecular Biology 11 82. (doi:10.1186/1471-2199-11-82)

Hodne K, von Krogh K, Weltzien FA, Sand O \& Haug TM 2012 Optimized conditions for primary culture of pituitary cells from the Atlantic cod (Gadus morhua). The importance of osmolality, $\mathrm{pCO}(2)$, and $\mathrm{pH}$. General and Comparative Endocrinology 178 206-215. (doi:10.1016/j. ygcen.2012.06.005)

Hodne K, Strandabo RAU, von Krogh K, Nourizadeh-Lillabadi R, Sand O, Weltzien FA \& Haug TM 2013 Electrophysiological differences between fshb- and lhb-expressing gonadotropes in primary culture. Endocrinology 154 3319-3330. (doi:10.1210/en.2013-1164)

Holland MCH, Hassin S \& Zohar Y 1998 Effects of long-term testosterone, gonadotropin-releasing hormone agonist, and pimozide treatments on gonadotropin II levels and ovarian development in juvenile female striped bass (Morone saxatilis). Biology of Reproduction 59 1153-1162. (doi:10.1095/biolreprod59.5.1153)

Huggard-Nelson DL, Nathwani PS, Kermouni A \& Habibi HR 2002 Molecular characterization of LH-beta and FSH-beta subunits and their regulation by estrogen in the goldfish pituitary. Molecular and Cellular Endocrinology 188 171-193. (doi:10.1016/S0303-7207(01)00716-X)

Huggard D, Khakoo Z, Kassam G, Mahmoud SS \& Habibi HR 1996 Effect of testosterone on maturational gonadotropin subunit messenger ribonucleic acid levels in the goldfish pituitary. Biology of Reproduction 54 1184-1191. (doi:10.1095/biolreprod54.6.1184)

Illing N, Troskie BE, Nahorniak CS, Hapgood JP, Peter RE \& Millar RP 1999 Two gonadotropin-releasing hormone receptor subtypes with distinct ligand selectivity and differential distribution in brain and pituitary in the goldfish (Carassius auratus). PNAS 96 2526-2531. (doi:10.1073/ pnas.96.5.2526)

Jørgensen A, Andersen O, Bjerregaard P \& Rasmussen LJ 2007 Identification and characterisation of an androgen receptor from zebrafish Danio rerio. Comparative Biochemistry and Physiology C-Toxicology and Pharmacology 146 561-568. (doi:10.1016/j.cbpc.2007.07.002)

Khan IA, Hawkins MB \& Thomas P 1999 Gonadal stage-dependent effects of gonadal steroids on gonadotropin II secretion in the Atlantic croaker (Micropogonias undulatus). Biology of Reproduction 61 834-841. (doi:10.1095/biolreprod61.3.834)

Kobayashi M, Aida K \& Hanyu I 1989 Induction of gonadotropin surge by steroid-hormone implantation in ovariectomized and sexually regressed female goldfish General and Comparative Endocrinology 73 469-476. (doi:10.1016/0016-6480(89)90204-9)

Kobayashi M, Sohn YC, Yoshiura Y \& Aida K 2000 Effects of sex steroids on the mRNA levels of gonadotropin subunits in juvenile and ovariectomized goldfish Carassius auratus. Fisheries Science 66 223-231. (doi:10.1046/j.1444-2906.2000.00038.x)

Larsen DA \& Swanson P 1997 Effects of gonadectomy on plasma gonadotropins I and II in coho salmon, Oncorhynchus kisutch. General and Comparative Endocrinology 108 152-160. (doi:10.1006/ gcen.1997.6958)

Latz M \& Reinboth R 1993 Androgen metabolism in the skin of the rainbow trout (Oncorhynchus mykiss).. Fish Physiology and Biochemistry 11 281-286. (doi:10.1007/BF00004576)

Levavi-Sivan B, Biran J \& Fireman E 2006 Sex steroids are involved in the regulation of gonadotropin-releasing hormone and dopamine D2 receptors in female tilapia pituitary. Biology of Reproduction 75 642-650. (doi:10.1095/biolreprod.106.051540)

Levavi-Sivan B, Bogerd J, Mananos EL, Gomez A \& Lareyre JJ 2010 Perspectives on fish gonadotropins and their receptors. General and Comparative Endocrinology 165 412-437. (doi:10.1016/j. ygcen.2009.07.019)

Lin S-W \& Ge W 2009 Differential regulation of gonadotropins (FSH and LH) and growth hormone $(\mathrm{GH})$ by neuroendocrine, endocrine, and paracrine factors in the zebrafish-An in vitro approach. General and Comparative Endocrinology 160 183-193. (doi:10.1016/j.ygcen.2008.11.020)

Lin CJ, Wu GC, Lee MF, Lau EL, Dufour S \& Chang CF 2010 Regulation of two forms of gonadotropin-releasing hormone receptor gene expression in the protandrous black porgy fish, Acanthopagrus schlegeli. Molecular and Cellular Endocrinology 323 137-146. (doi:10.1016/j. mce.2010.04.003)

Marchant TA, Chang JP, Nahorniak CS \& Peter RE 1989 Evidence that gonadotropin-releasing hormone also functions as a growth hormonereleasing factor in the goldfish. Endocrinology 124 2509-2518. (doi:10.1210/endo-124-5-2509)

Margiotta-Casaluci L, Courant F, Antignac J-P, Le Bizec B \& Sumpter JP 2013 Identification and quantification of 5 alpha-dihydrotestosterone in the teleost fathead minnow (Pimephales promelas) by gas chromatography-tandem mass spectrometry. General and Comparative Endocrinology 191 202-209. (doi:10.1016/j.ygcen.2013.06.017)

Martyniuk CJ, Kroll KJ, Porak WF, Steward C, Grier HJ \& Denslow ND 2009 Seasonal relationship between gonadotropin, growth hormone, and estrogen receptor mRNA expression in the pituitary gland of largemouth bass. General and Comparative Endocrinology 163 306-317. (doi:10.1016/j.ygcen.2009.04.028)

Martyniuk CJ, Bissegger S \& Langlois VS 2013 Current perspectives on the androgen 5 alpha-dihydrotestosterone (DHT) and 5 alpha-reductases in teleost fishes and amphibians. General and Comparative Endocrinology 194 264-274. (doi:10.1016/j.ygcen.2013.09.019)

Mateos J, Mananos E, Carrillo M \& Zanuy S 2002 Regulation of folliclestimulating hormone (FSH) and luteinizing hormone (LH) gene expression by gonadotropin-releasing hormone $(\mathrm{GnRH})$ and sexual steroids in the Mediterranean Sea bass. Comparative Biochemistry and Physiology B-Biochemistry and Molecular Biology 132 75-86. (doi:10.1016/S1096-4959(01)00535-8)

Melamed P, Gur G, Rosenfeld H, Elizur A \& Yaron Z 1997 The mRNA levels of $\mathrm{GtH}$ I beta, GtH II beta and $\mathrm{GH}$ in relation to testicular development and testosterone treatment in pituitary cells of male tilapia. Fish Physiology and Biochemistry 17 93-98. (doi:10.1023/A:1007737414565)

Mittelholzer C, Andersson E, Taranger GL, Karlsen Ø \& Norberg B 2009 Quantification of gonadotropin subunits GP alpha, FSH beta, and LH 
beta mRNA expression from Atlantic cod (Gadus morhua) throughout a reproductive cycle. Comparative Biochemistry and Physiology B-Biochemistry and Molecular Biology 153 288-295. (doi:10.1016/j. cbpb.2009.03.011)

Nagasawa K, Presslauer C, Kirtiklis L, Babiak I \& Fernandes JMO 2014 Sexually dimorphic transcription of estrogen receptors in cod gonads throughout a reproductive cycle. Journal of Molecular Endocrinology 52 357-371. (doi:10.1530/JME-13-0187)

Norberg B, Brown CL, Halldorsson A, Stensland K \& Björnsson BT 2004 Photoperiod regulates the timing of sexual maturation, spawning, sex steroid and thyroid hormone profiles in the Atlantic cod (Gadus morhua). Aquaculture 229 451-467. (doi:10.1016/S0044-8486(03)00393-4)

Okuzawa K 2002 Puberty in teleosts. Fish Physiology and Biochemistry 26 31-41. (doi:10.1023/A:1023395025374)

Parhar IS, Soga T, Sakuma Y \& Millar RP 2002 Spatio-temporal expression of gonadotropin-releasing hormone receptor subtypes in gonadotropes, somatotropes and lactotropes in the cichlid fish. Journal of Neuroendocrinology 14 657-665. (doi:10.1046/j.13652826.2002.00817.x)

Parhar IS, Ogawa S \& Sakuma Y 2005 Three GnRH receptor types in lasercaptured single cells of the cichlid pituitary display cellular and functional heterogeneity. PNAS 102 2204-2209. (doi:10.1073/pnas.0409494102)

Pasmanik M \& Callard GV 1988a Changes in brain aromatase and 5-alphareductase activities correlate significantly with seasonal reproductive cycles in goldfish (Carassius auratus).. Endocrinology 122 1349-1356. (doi:10.1210/endo-122-4-1349)

Pasmanik M \& Callard GV 1988b A high abundance androgen receptor in goldfish brain - characteristics and seasonal changes. Endocrinology 123 1162-1171. (doi:10.1210/endo-123-2-1162)

Pfaffl MW 2001 A new mathematical model for relative quantification in real-time RT-PCR. Nucleic Acids Research 29 2002-2007. (doi:10.1093/ nar/29.9.e45)

Pfaffl MW, Tichopad A, Prgomet C \& Neuvians TP 2004 Determination of stable housekeeping genes, differentially regulated target genes and sample integrity: bestKeeper - excel-based tool using pairwise correlations. Biotechnology Letters 26 509-515. (doi:10.1023/ B:BILE.0000019559.84305.47)

Quinones-Jenab V, Jenab S, Ogawa S, Funabashi T, Weesner GD \& Pfaff DW 1996 Estrogen regulation of gonadotropin-releasing hormone receptor messenger RNA in female rat pituitary tissue. Molecular Brain Research 38 243-250. (doi:10.1016/0169-328X(95)00322-J)

Rebers FEM, Tensen CP, Schulz RW, Goos HJT \& Bogerd J 1997 Modulation of glycoprotein hormone alpha- and gonadotropin II beta-subunit mRNA levels in the pituitary gland of mature male African catfish, Clarias gariepinus. Fish Physiology and Biochemistry 17 99-108. (doi:10.102 3/A:1007725321061)

Rebers FEM, Hassing GAM, Zandbergen MA, Goos HJT \& Schulz RW 2000 Regulation of steady-state luteinizing hormone messenger ribonucleic acid levels, de novo synthesis, and release by sex steroids in primary pituitary cell cultures of male African catfish, Clarias gariepinus. Biology of Reproduction 62 864-872. (doi:10.1095/biolreprod62.4.864)

Roche 2001 Roche applied science. Technical note No. LC 13. Available at: www.gene-quantification.com/roche-rel-quant.pdf

Saligaut C, Linard B, Breton B, Anglade I, Bailhache T, Kah O \& Jego P 1999 Brain aminergic systems in salmonids and other teleosts in relation to steroid feedback and gonadotropin release. Aquaculture 177 13-20. (doi:10.1016/S0044-8486(99)00065-4)

Santos NC, Figueira-Coelho J, Saldanha C \& Martins-Silva J 2002 Biochemical, biophysical and haemorheological effects of dimethylsulphoxide on human erythrocyte calcium loading. Cell Calcium 31 183-188. (doi:10.1054/ceca.2002.0271)
Shivaji S \& Jagannadham MV 1992 Steroid-induced pertubations of membranes and its relevance to sperm acrosome reaction. Biochimica Et Biophysica Acta 1108 99-109. (doi:10.1016/00052736(92)90119-7)

Sohn YC, Yoshiura Y, Kobayashi M \& Aida K 1998 Effect of sex steroids on the mRNA levels of gonadotropin I and II subunits in the goldfish Carassius auratus. Fisheries Science 64 715-721. (doi:10.2331/fishsci.64.715)

Sohn YC, Kobayashi M \& Aida K 2001 Regulation of gonadotropin beta subunit gene expression by testosterone and gonadotropinreleasing hormones in the goldfish, Carassius auratus. Comparative Biochemistry and Physiology B-Biochemistry and Molecular Biology 129 419-426. (doi:10.1016/S1096-4959(01)00342-6)

Sperry TS \& Thomas P 1999 Identification of two nuclear androgen receptors in kelp bass (Paralabrax clathratus) and their binding affinities for xenobiotics: comparison with Atlantic croaker (Micropogonias undulatus) androgen receptors. Biology of Reproduction 61 1152-1161. (doi:10.1095/biolreprod61.4.1152)

Taranger GL, Carrillo M, Schulz RW, Fontaine P, Zanuy S, Felip A, Weltzien FA, Dufour S, Karlsen Ø, Norberg B et al. 2010 Control of puberty in farmed fish. General and Comparative Endocrinology 165 483-515. (doi:10.1016/j.ygcen.2009.05.004)

Tse ACK, Lau KYT, Ge W \& Wu RSS 2013 A rapid screening test for endocrine disrupting chemicals using primary cell culture of the marine medaka. Aquatic Toxicology 144 50-58. (doi:10.1016/j.aquatox.2013.09.022)

Weltzien FA, Andersson E, Andersen Ø, Shalchian-Tabrizi K \& Norberg B 2004 The brain-pituitary-gonad axis in male teleosts, with special emphasis on flatfish (pleuronectiformes). Comparative Biochemistry and Physiology A-Molecular and Integrative Physiology 137 447-477. (doi:10.1016/j.cbpb.2003.11.007)

Weltzien FA, Pasqualini C, Vernier P \& Dufour S 2005 A quantitative real-time RT-PCR assay for European eel tyrosine hydroxylase. General and Comparative Endocrinology 142 134-142. (doi:10.1016/j. ygcen.2004.12.019)

Whiting KP, Restall CJ \& Brain PF 2000 Steroid hormone-induced effects on membrane fluidity and their potential roles in non-genomic mechanisms. Life Sciences 67 743-757. (doi:10.1016/S0024-3205(00)00669-X)

Yamaguchi S, Gen K, Okuzawa K, Matsuyama M \& Kagawa H 2006 Influence of estradiol-17 beta, testosterone, and 11-ketotestosterone on testicular development, serum steroid hormone, and gonadotropin secretion in male red sea bream Pagrus major. Fisheries Science $\mathbf{7 2}$ 835-845. (doi:10.1111/j.1444-2906.2006.01225.x)

Yen FP, Lee YH, He CL, Huang JD, Sun LT, Dufour S \& Chang CF 2002 Estradiol-17 beta triggers luteinizing hormone release in the protandrous black porgy (Acanthopagrus schlegeli bleeker) through multiple interactions, with gonadotropin-releasing hormone control. Biology of Reproduction 66 251-257. (doi:10.1095/biolreprod66.1.251)

ZoharY,Antonio Munoz-Cueto], ElizurA\& Kah O2010 Neuroendocrinology of reproduction in teleost fish. General and Comparative Endocrinology 165 438-455. (doi:10.1016/j.ygcen.2009.04.017)

Received 12 April 2017

First decision 25 May 2017

Revised manuscript received 23 July 2017

Accepted 31 July 2017 